\title{
A comparison of the efficacy of pond-net and box sampling methods in turloughs - Irish ephemeral aquatic systems
}

\author{
Áine O Connor ${ }^{1,2, *}$, Stephen Bradish ${ }^{1}$, Thomas Reed ${ }^{1}$, James Moran ${ }^{1}$, Eugenie Regan ${ }^{1}$, \\ Marjolein Visser ${ }^{1}$, Mike Gormally ${ }^{1} \&$ Micheline Sheehy Skeffington ${ }^{3}$ \\ ${ }^{1}$ Applied Ecology Unit, Centre for Environmental Science, Department of Microbiology, NUI Galway, Galway, Ireland \\ ${ }^{2}$ Present address: National Parks and Wildlife Service, Department of Environment Heritage and Local Government, \\ 7 Ely Place, Dublin 2, Ireland \\ ${ }^{3}$ Present address: Department of Botany, NUI Galway, Galway, Ireland \\ (*Author for correspondence: Tel.: +353-1-6472371,E-mail: aoconnor@duchas.ie)
}

Received 16 June 2003; in revised form 9 January 2003; accepted 16 January 2004

Key words: pond net, box method, turloughs, littoral macroinvertebrates

\begin{abstract}
Two methods were used to sample aquatic macroinvertebrates in three turloughs. Turloughs are systems that flood periodically from groundwater, in response to local rainfall patterns and contain rare aquatic species and assemblages. The first method used a standard pond net that was swept through the water column, while the second involved fixing a rectangular, open-bottomed box to the substrata and removing all organisms with a net. Similar overall sampling effort was applied to each method and individual box samples were found to take longer to gather than pond net samples. The box method, however, gave the maximum yield for a given sampling effort. Significantly more beetle species and individuals were recorded per unit area of bottom at all three turloughs using the box method. Multivariate analysis segregated samples, firstly according to site and secondly, with respect to method. The box method is a viable alternative to sampling with a pond net. It is more quantitative, objective, specific and reliable. This is particularly important in habitats distinguished by rare species and assemblages, and for which monitoring is driven by legislative needs.
\end{abstract}

\section{Introduction}

Lotic macroinvertebrate sampling methods have received a disproportionate amount of attention in the literature (e.g. Macan, 1958; Cummins, 1962; Crossman \& Cairns, 1974; Furse et al., 1981; Mackey et al., 1984; Humphries et al., 1998; Metzeling \& Miller, 2001) compared with lentic methods (Macan, 1977; Cheal et al., 1992; Muzaffar \& Colbo, 2002). This is largely a result of the widespread use of aquatic invertebrates in the biological monitoring of stream/river quality, e.g. RIVPACS in the UK (Wright et al., 1984; Cox et al., 1995); Q-value system in Ireland (Flanagan
\& Toner, 1972) and AusRivAs in Australia (Marchant et al., 1997; Turak \& Waddell, 2002). Although a variety of samplers have been described (e.g. Macan, 1958; Cummins, 1962; Hilsenhoff, 1969; Maitland, 1969; Crossman \& Cairns, 1974; Croset et al., 1976; Elliott \& Tullet, 1978), the pond net remains the most popular device employed in freshwaters. While procedures have been described for pond net sampling of lotic systems (SAC, 1978; I.S.O., 1985) no standardised technique has been designed for lentic systems. Pond nets may be swept or 'shuffled' (in a 
modification of the lotic kick-sampling method) and the size of the sample can be determined by time, distance, area or number of sweeps. Sweeping is best adapted to macrophyte beds and soft substrata, while 'shuffling' is used in stony or gravelly substrata. Although the pond net is a flexible, easily employed and cost-efficient method, it does present a number of problems. Pond netting is not quantitative, it does not capture organisms which are hidden in dense vegetation or buried in the substrata and it cannot be used to sample specific, homogenous micro-habitats. In order to overcome these difficulties, freshwater biologists have repeatedly come up with the same solution: a device to physically isolate an area of bottom and volume of water from which all trapped macroinvertebrates are netted or sieved (Bates, 1941; Goodwin \& Eyles, 1942; Macan, 1958; James \& Nicholls, 1961; de Eyto, 1999; O Connor, 2000). The shape of these devices has varied from cylinders (Macan, 1958; O Connor, 2000), to squares and rectangles (Bates, 1941; Goodwin \& Eyles, 1942; Macan, 1958; James \& Nicholls, 1961; de Eyto, 1999), with the area of bottom enclosed also varying widely. In this study, the sampling efficiency of a rectangular frame or 'box' was compared with a pond net method, for collection of invertebrates in the lentic environment of turloughs.

Turloughs are ephemeral systems found over karstified Carboniferous limestone, which fill and empty in response to fluctuations in the local water table (Reynolds, 1982, 1996; Coxon, 1987a; Reynolds et al., 1998). This generally means they are flooded in the northern hemisphere winter and are dry in summer. They are a priority for conserva- tion, as their distribution is more or less restricted to Ireland and because of the importance of their geological, hydrological and biological characteristics, and are listed as priority habitats in Annex I of the European Union's Habitats Directive (92/ 43/EEC). Turloughs are distinguished from other temporary water bodies in that they fill from, and empty to, the groundwater through conduits known as 'swallow-holes' or 'slugaire' (Coxon, 1987b, 1994; Reynolds, 1996). Rare species and assemblages of flora and fauna have been recorded in turloughs (Praeger, 1932; MacGowran, 1979; O'Connell et al., 1984; Coxon, 1987b; Lott \& Bilton, 1991; Goodwillie et al., 1997; Owen, 1997; Good \& Butler, 2001; Ní Bhríaín et al., 2002; Ryder et al., 2003; Ryder et al., in press), including diverse and characteristic communities of crustaceans (Reynolds, 1985, 1996, 2000; Ali et al., 1987; Duigan \& Frey, 1987a, b; Duigan, 1988; Grainger \& Holmes, 1989; Reynolds \& Marnell, 1999) and aquatic beetles (Bilton, 1988; Bilton \& Lott, 1991; Foster et al., 1992; Bradish et al., 2002). Turlough littoral zones can include terrestrial grassland plants, limestone pavement, stone wall field boundaries and even woodland ground flora. Within Ireland (Fig. 1), the majority of turloughs are found to the west and north of the River Shannon (Coxon, 1987a).

\section{Description of sites studied}

Three turloughs in south-east county Galway were chosen for their similarity in area (Goodwillie et al., 1997) (Fig. 1). Caranavoodaun $\left(051^{\circ} 14^{\prime} 17^{\prime \prime} \mathrm{N}, 010^{\circ} 50^{\prime} 36^{\prime \prime} \mathrm{W}\right.$, Irish grid

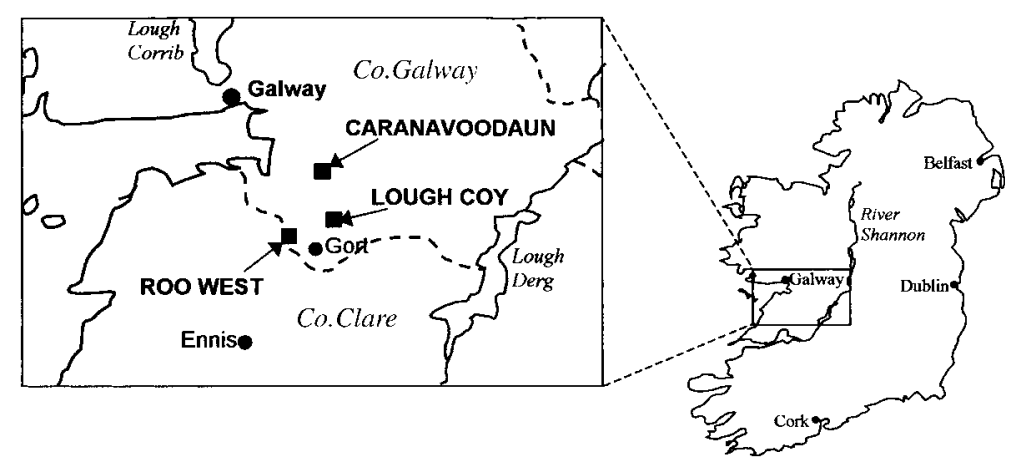

Figure 1. Map of Gort Area, Co. Galway, Ireland showing the three turloughs studied. 
reference M455155, area 31 ha) is surrounded by hazel woodland and limestone heath and has a shallow basin containing areas of exposed limestone and extensive stone walls. It retains a small pool of water throughout most years. Lough Coy (051 $14^{\prime} 17^{\prime \prime} \mathrm{N}, 010^{\circ} 50^{\prime} 35^{\prime \prime} \mathrm{W}, \mathrm{M} 490075,36$ ha) is separated from intensively managed agricultural land by a boundary of scrub. It occupies a deep, steep-sided depression, has some rock outcrops and retains a small permanent lake. Roo West $\left(051^{\circ} 14^{\prime} 14^{\prime \prime} \mathrm{N}, 010^{\circ} 5^{\prime} 40^{\prime \prime} \mathrm{W}, \mathrm{M} 385022,28\right.$ ha) is surrounded by an extensive area of exposed karstified limestone, is situated in a shallow basin and has a small permanent marl pond. All three turloughs are grazed: Caranavoodaun by horses and cattle, Lough Coy by cattle and Roo West by cattle and sheep.

\section{Materials and methods}

Roo West was sampled over three days, the 5th, 8th and 12th November 2001, while Caranavoodaun was sampled on 19th November and Lough Coy on 22nd November 2001.

\section{Pond net sampling}

Thirty sampling stations were selected randomly at Caranavoodaun and Lough Coy, while 40 were chosen at Roo West. Random distribution of sampling stations was achieved by pacing the shoreline of the turlough and then generating 3040 random numbers between zero and the total number of paces. One sample was taken at each sampling station. A standard FBA pond net ( $0.9 \mathrm{~mm}$ mesh, $24.5 \times 28.0 \mathrm{~cm}$ D-shaped frame) collected samples at a water depth of $25-30 \mathrm{~cm}$. The net was swept sideways along a $1 \mathrm{~m}$ path and turned back along the same path to collect dislodged organisms, allowing the frame to graze the surface of the substrata with each pass.

\section{Box sampling}

Sixteen samples were taken from Caranavoodaun and Lough Coy and 18 from Roo West. The objective of the box sampling was to examine the spatial distribution of macroinvertebrates in turlough microhabitats and an approximately equal number of samples was taken from both open sward and along stonewalls. The box frame was created by cutting the bottom out of a sturdy, plastic storage box $(39.0 \mathrm{~cm}$ long $\times 31.5$ wide $\times 23.0$ high). At each sampling station, the box was rapidly and vertically lowered through the water column and held firmly against the substrata (submerged terrestrial vegetation). Organisms trapped within the box were then removed using an aquarium-style fish net $(0.8 \mathrm{~mm}$ mesh, $12.5 \times 10.0 \mathrm{~cm}$ frame). This procedure was repeated three times at each sampling station along contiguous areas of bottom and the contents pooled to give one sample.

An individual operator employed each method in the field (pond net - S.B., box - T.R.). Both operators spent a roughly equivalent length of time sampling each turlough, resulting in the pond net method collecting almost double the number of samples for the same unit of time. All samples were sieved and preserved in $75 \%$ industrial alcohol in the field. Samples were sorted in the laboratory, invertebrates were identified using the keys of Macan (1977), Elliott \& Mann (1979), Elliott et al. (1988), Friday (1988), Savage (1989), Wallace et al. (1990) and Gledhill et al. (1993). Oligochaetes, bivalves, water mites and dipteran larvae were not identified further than family, but were included in the analysis as operational taxonomic units.

Summary statistics and graphs were generated using Microsoft Excel. The data were ordinated by Nonmetric Multidimensional Scaling (NMS) using PC-ORD 4.17 for Windows. Mann-Whitney $U$ tests were computed on medians using GraphPad InStat 3.05.

\section{Results}

The pond net method yielded lower overall species richness than the box method at all three turloughs, with 32 species captured using the pond net method compared with 50 with the box method at Caranavoodaun, 27 compared with 37 at Lough Coy and 27 compared with 38 at Roo West (Table 1). At Caranavoodaun, six species captured with the pond net were not taken with the box, while 24 species were captured with the box but not the pond net. Results were similar at 
Table 1. Full species list and number of individuals sampled for the three turloughs. P-N - pond net, $\mathrm{B}-$ box, $n-$ total number of samples

\begin{tabular}{|c|c|c|c|c|c|c|}
\hline & \multicolumn{2}{|c|}{ Caranavoodaun } & \multicolumn{2}{|c|}{ Lough Coy } & \multicolumn{2}{|c|}{ Roo West } \\
\hline & $\mathrm{P}-\mathrm{N}$ & $\mathrm{B}$ & $\mathrm{P}-\mathrm{N}$ & B & $\mathrm{P}-\mathrm{N}$ & $\mathrm{B}$ \\
\hline$n$ & 30 & 16 & 30 & 16 & 40 & 18 \\
\hline \multicolumn{7}{|l|}{ PLANARIIDAE } \\
\hline Polycelis nigra & 214 & 8 & & & 32 & 5 \\
\hline \multicolumn{7}{|l|}{ HYGROBIIDAE } \\
\hline Potamopyrgus jenkinsi & & & 4 & & 1 & \\
\hline Bithynia tentaculata & 65 & 16 & & 3 & 24 & 23 \\
\hline \multicolumn{7}{|l|}{ LYMNAEIDAE } \\
\hline Lymnaea palustris & 56 & 6 & & & 27 & \\
\hline Lymnaea peregra & 17 & 3 & 7 & & 8 & \\
\hline \multicolumn{7}{|l|}{ PHYSIDAE } \\
\hline Physa fontinalis & & 1 & & & & 1 \\
\hline Aplexa hypnorum & 9 & & & & 1 & \\
\hline \multicolumn{7}{|l|}{ PLANORBIDAE } \\
\hline Planorbis albus & 10 & & 13 & 3 & 55 & \\
\hline Planorbis carinatus & & & & 1 & & \\
\hline Planorbis leucostoma & 26 & 2 & & & 37 & 1 \\
\hline Planorbis planorbis & & & & & & 8 \\
\hline \multicolumn{7}{|l|}{ SUCCINEIDAE } \\
\hline Succinea sp. & & 7 & & 1 & & \\
\hline \multicolumn{7}{|l|}{ ZONITIDAE } \\
\hline Zonitoides sp. & 1 & & 15 & & & \\
\hline Bivalves & & 1 & & & & 1 \\
\hline Oligochaetes & & 5 & & & & 30 \\
\hline \multicolumn{7}{|l|}{ GLOSSIPHONIIDAE } \\
\hline Glossiphonia complanata & & 1 & & 5 & & \\
\hline Theromyzon tessulatum & & 2 & 13 & 18 & & 1 \\
\hline \multicolumn{7}{|l|}{ HIRUDINIDAE } \\
\hline Haemopis sanguisuga & & 1 & & & & \\
\hline Hydracarina & 19 & 25 & & 1 & 10 & 6 \\
\hline \multicolumn{7}{|l|}{ ASELLIDAE } \\
\hline Asellus aquaticus & & 1 & 2 & 64 & & \\
\hline Asellus meridianus & & & & & 3 & 1 \\
\hline \multicolumn{7}{|l|}{ GAMMARIDAE } \\
\hline Gammarus duebeni & & & & & & 1 \\
\hline Gammarus lacustris & 2 & 5 & 7 & 13 & 19 & 10 \\
\hline \multicolumn{7}{|l|}{ BAETIDAE } \\
\hline Cloeon dipterum & 155 & 20 & & & 1 & \\
\hline Dragonfly larvae & 21 & 6 & & & & \\
\hline \multicolumn{7}{|l|}{ NEPIDAE } \\
\hline Nepa cinerea & & & & 1 & & \\
\hline \multicolumn{7}{|l|}{ NOTONECTIDAE } \\
\hline Notonecta glauca & 4 & 1 & & 2 & 1 & 2 \\
\hline
\end{tabular}


Table 1. (Continued)

\begin{tabular}{|c|c|c|c|c|c|c|}
\hline \multirow[b]{3}{*}{$n$} & \multicolumn{2}{|c|}{ Caranavoodaun } & \multicolumn{2}{|c|}{ Lough Coy } & \multicolumn{2}{|c|}{ Roo West } \\
\hline & $\mathrm{P}-\mathrm{N}$ & $\mathrm{B}$ & $\mathrm{P}-\mathrm{N}$ & $\mathrm{B}$ & $\mathrm{P}-\mathrm{N}$ & B \\
\hline & 30 & 16 & 30 & 16 & 40 & 18 \\
\hline \multicolumn{7}{|l|}{ CORIXIDAE } \\
\hline Arctocorisa germari & & & 19 & 1 & & \\
\hline Callicorixa praeusta & & & 1 & 1 & & \\
\hline Corixa panzeri & & & 10 & 3 & & \\
\hline Sigara concinna & & & 252 & 23 & 1 & \\
\hline Sigara dorsalis & & & & 1 & & \\
\hline Sigara falleni & & & 370 & 26 & & \\
\hline Sigara lateralis & 3 & 1 & 16 & 2 & & \\
\hline Sigara scotti & & & 1 & & & \\
\hline Sigara other & & & 2 & & & \\
\hline Corixid larva & 1 & & & 1 & & \\
\hline \multicolumn{7}{|l|}{ LIMNEPHILIDAE } \\
\hline Grammotaulius nigropunctatus & 147 & 75 & 15 & 1 & 28 & 2 \\
\hline Limnephilus qffinis/incisus & & & 3 & 6 & 47 & 26 \\
\hline Limnephilus auricula & 5 & & 15 & & & \\
\hline Limnephilus binotatus & 10 & 22 & 3 & 3 & & 19 \\
\hline Limnephilus decipiens & & 2 & & & & \\
\hline Limnephilus flavicornis & & 21 & & & & \\
\hline Limnephilus rhombicus & 140 & 169 & 19 & & 23 & 30 \\
\hline Limnephilus vittatus & 94 & 23 & & & 271 & 13 \\
\hline Dipteran larvae & 39 & 12 & & & & 61 \\
\hline Unidentified larvae & & 11 & & 4 & & 5 \\
\hline \multicolumn{7}{|l|}{ HALIPLIDAE } \\
\hline Haliplus confinis & & 3 & & 2 & & \\
\hline Haliplus fulvus & & 1 & & & & \\
\hline Haliplus lineatocollis & & & & & 3 & \\
\hline Haliplus rufficollis-group & & 2 & & & & \\
\hline Haliplus variegatus & 2 & 4 & & 1 & & \\
\hline \multicolumn{7}{|l|}{ HYGROBIIDAE } \\
\hline Hygrobia hermanni & & & 1 & & & \\
\hline \multicolumn{7}{|l|}{ NOTERIDAE } \\
\hline Noterus clavicornis & & 6 & & 1 & & \\
\hline \multicolumn{7}{|l|}{ DYTISCIDAE } \\
\hline Hygrotus inaequalis & & 9 & & 48 & 2 & 4 \\
\hline Hygrotus quinquelineatus & 2 & 2 & 1 & & 1 & 2 \\
\hline Hygrotus impressopunctatus & & 2 & & & & \\
\hline Hydroporus erythrocephalus & & 1 & & 2 & & 3 \\
\hline Hydroporus memnonius & & & & & & 1 \\
\hline Hydroporus palustris & 26 & 22 & 7 & 16 & 7 & 3 \\
\hline Hydroporus pubescens & & & & & & 1 \\
\hline Porhydrus lineatus & 7 & 1 & & 1 & & \\
\hline Graptodytes bilineatus & 1 & 2 & & & 50 & 22 \\
\hline Suphrodytes dorsalis & & & & & & 1 \\
\hline
\end{tabular}


Table 1. (Continued)

\begin{tabular}{|c|c|c|c|c|c|c|}
\hline \multirow[b]{3}{*}{$n$} & \multicolumn{2}{|c|}{ Caranavoodaun } & \multicolumn{2}{|c|}{ Lough Coy } & \multicolumn{2}{|c|}{ Roo West } \\
\hline & $\mathrm{P}-\mathrm{N}$ & $\mathrm{B}$ & $\mathrm{P}-\mathrm{N}$ & B & $\mathrm{P}-\mathrm{N}$ & $\mathrm{B}$ \\
\hline & 30 & 16 & 30 & 16 & 40 & 18 \\
\hline \multicolumn{7}{|l|}{ DYTISCIDAE } \\
\hline Agabus bipustulatus & & 4 & & 1 & & 6 \\
\hline Agabus labiatus & 4 & 4 & & & 2 & 5 \\
\hline Agabus melanocornis & & 1 & & & & 1 \\
\hline Agabus nebulosus & & 5 & 1 & 10 & 9 & 19 \\
\hline Ilybius fuliginosus & & & & 1 & & \\
\hline Colymbetes fuscus & & 7 & & 3 & & 19 \\
\hline Laccophilus minuntus & 1 & 11 & 1 & 81 & 2 & 5 \\
\hline Dystiscus circumcinctus & & & 1 & & & \\
\hline Dytiscus semisulcatus & 1 & & & & & \\
\hline \multicolumn{7}{|l|}{ HYDRAENIDAE } \\
\hline Ochthebius minimus & & 1 & & & & \\
\hline \multicolumn{7}{|l|}{ HELOPHORIDAE } \\
\hline Helophorus brevipalpis & 1 & 7 & & & 1 & 4 \\
\hline Helophorus grandis & & & & & & 4 \\
\hline \multicolumn{7}{|l|}{ HYDROPHILIDAE } \\
\hline Berosus signaticollis & 38 & 42 & & & & \\
\hline \multicolumn{7}{|l|}{ DRYOPIDAE } \\
\hline Dryops species & & 7 & & 3 & & 20 \\
\hline Beetle larvae & 47 & 45 & 20 & 16 & & 7 \\
\hline Total number of individuals & 116 & 636 & 819 & 370 & 666 & 373 \\
\hline Total number of species & 32 & 50 & 27 & 37 & 27 & 38 \\
\hline
\end{tabular}

Lough Coy and Roo West, with 11 and nine species, respectively, taken with the pond net and not found in box samples and 21 and 20 species, respectively, recorded with the box only.

Summary statistics were calculated for the number of species and the number of individuals per pond net and box sample (Tables 2 and 3 ). In order to compare the sampling methods more quantitatively, means and medians per $1000 \mathrm{~cm}^{2}$ of bottom were calculated. Each pond net sample was estimated to cover an area of $2450 \mathrm{~cm}^{2}$ $(24.5 \times 100 \mathrm{~cm})$, while each box sample was known to cover an area of $3686 \mathrm{~cm}^{2}$. No significant differences in median number of species were found between sampling methods. The median number of individuals per sample was not significantly different between methods at Caranavoodaun and Roo West (Table 3), but the pond

Table 2. The mean ( \pm standard deviation), median and range of number of species per $1000 \mathrm{~cm}^{2}$ of bottom ( $n$ is the total number of samples)

\begin{tabular}{|c|c|c|c|c|c|c|c|c|c|c|c|c|}
\hline & \multicolumn{4}{|c|}{ Caranavoodaun } & \multicolumn{4}{|c|}{ Lough Coy } & \multicolumn{4}{|c|}{ Roo West } \\
\hline & $n$ & Mean & Median & Range & $n$ & Mean & Median & Range & $n$ & Mean & Median & Range \\
\hline Pond-net & 30 & $3 \pm 1$ & 3 & $1-6$ & 30 & $2 \pm 1$ & 2 & $0-4$ & 40 & $2 \pm 1$ & 2 & $0-4$ \\
\hline Box & 16 & $3 \pm 1$ & 3 & $1-5$ & 16 & $2 \pm 1$ & 2 & $1-4$ & 18 & $2 \pm 1$ & 2 & $0-4$ \\
\hline
\end{tabular}


Tabla 3. The mean ( \pm standard deviation), median and range of number of individuals per $1000 \mathrm{~cm}^{2}$ of bottom $(n$ is the total number of samples)

\begin{tabular}{|c|c|c|c|c|c|c|c|c|c|c|c|c|}
\hline & \multicolumn{4}{|c|}{ Caranavoodaun } & \multicolumn{4}{|c|}{ Lough Coy } & \multicolumn{4}{|c|}{ Roo West } \\
\hline & $n$ & Mean & Median & Range & $n$ & Mean & Median & Range & $n$ & Mean & Median & Range \\
\hline Pond-net & 30 & $20 \pm 15$ & 15 & $4-57$ & 30 & $11 \pm 9$ & $9 *$ & $0-35$ & 40 & $7 \pm 6$ & 4 & $0-24$ \\
\hline Box & 16 & $12 \pm 6$ & 13 & $1-24$ & 16 & $6 \pm 5$ & $6^{*}$ & $1-22$ & 18 & $6 \pm 6$ & 5 & $1-9$ \\
\hline
\end{tabular}

Values with asterisks indicate significant differences between the medians.

net yielded significantly greater numbers per $1000 \mathrm{~cm}^{2}$ at Lough Coy $(U=138, p=0.0193$, Mann-Whitney $U$ test). The pond net method sampled lower beetle species richness than the box at each turlough, respectively 10 compared with 22 at Caranavoodaun, six compared with 13 at Lough Coy and nine compared with 17 at Roo West (Table 1). Median species richness for beetles was also significantly less using the pond net method when adjusted for area of bottom (Caranavoodaun $U=94.5, \quad p=0.0008 ;$ Lough Coy $U=123, p=0.007$; Roo West $U=175$, $p=0.0019$; Mann-Whitney $U$ test). The pond net method also produced a lower total catch of beetles at all turloughs ( 83 compared with 144 at Caranavoodaun, 12 compared with 170 at Lough Coy and 77 compared with 120 at Roo West) (Table 1). The median number of beetles captured per $1000 \mathrm{~cm}^{2}$ using the pond net method, was significantly lower at Caranavoodaun ( $U=125.5, p=0.0086$; Mann-Whitney $U$ test $)$, Lough Coy $(U=104, p=0.0017$; Mann-whitney $U$ test) and Roo West ( $U=181, p=0.0027$; Mann-Whitney $U$ test). Corixids were abundant at Lough Coy and significantly greater median numbers per $1000 \mathrm{~cm}^{2}$ were captured with the pond net $(U=61.5, p<0.0001$; Mann-Whitney $U$ test).
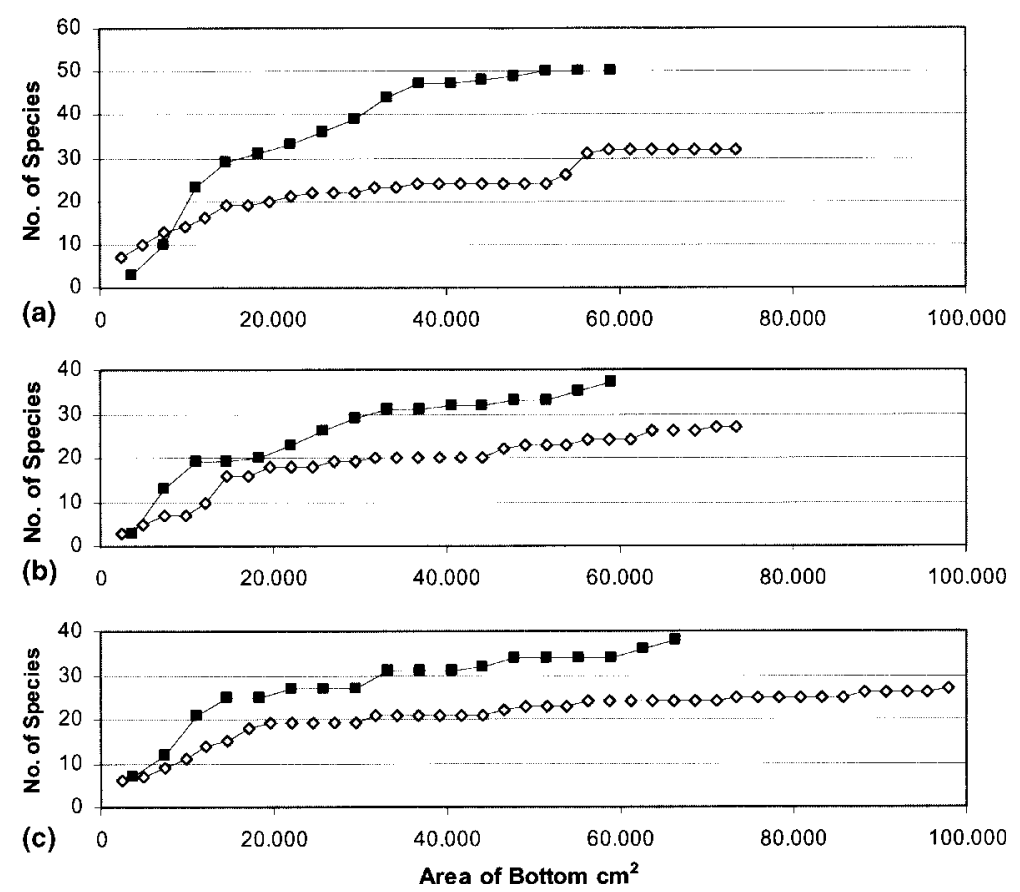

Figure 2. Family accretion curves for Caranavoodaun (a), Lough Coy (b) and Roo West (c). Open diamonds show the pond-net method, closed squares the box method. 

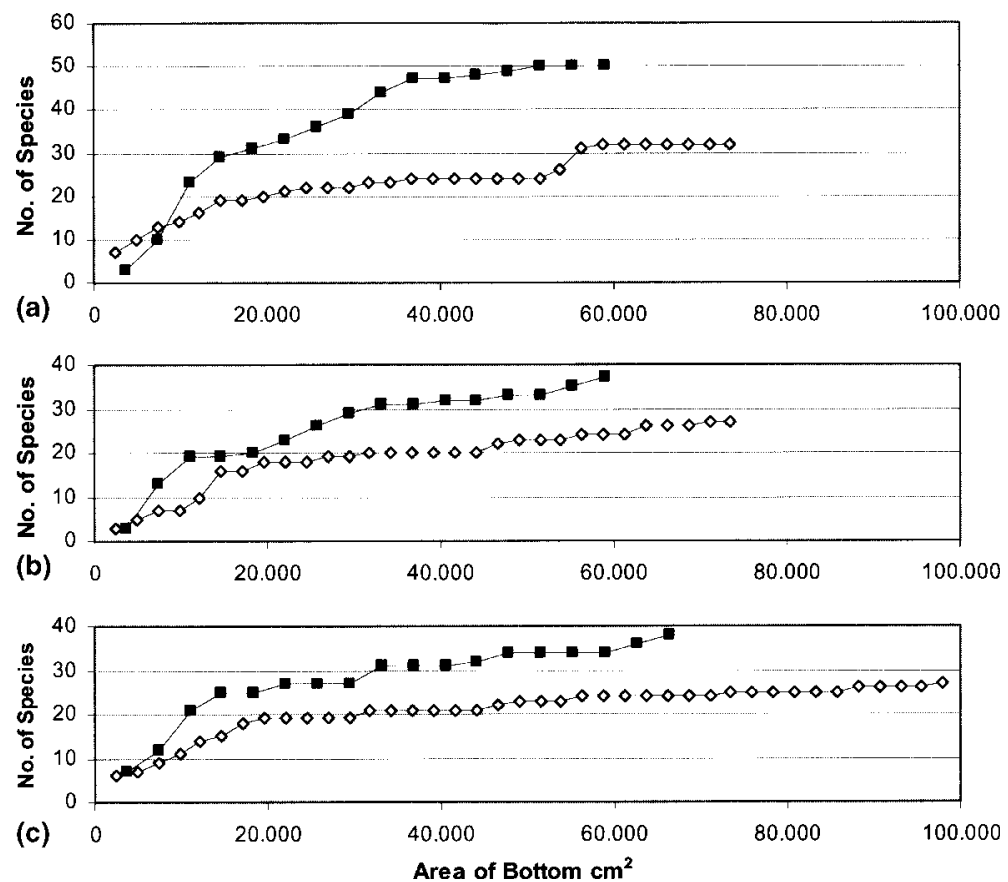

Figure 3. Species accretion curves for Caranavoodaun (a), Lough Coy (b) and Roo West (c). Open diamonds show the pond-net method, closed squares the box method.

Taxon accretion curves were drawn for families (Fig. 2) and species (Fig. 3). As the sampling stations were selected randomly, samples were arranged sequentially and the cumulative number of families/species counted. Fewer families were recorded using the pond net method than the box method at all three turloughs (eight fewer families at Caranavoodaun, five at Lough Coy and three at Roo West) (Fig. 2). The initial increase in families with area sampled was more rapid with the box method. After $11057 \mathrm{~cm}^{2}$, or three samples, $63 \%$ of all families recorded using the box method were captured at Caranavoodaun, $71 \%$ at Lough Coy and $67 \%$ at Roo West. After $12250 \mathrm{~cm}^{2}$, or five pond net samples, respectively 53,58 and 53\% were captured at Caranavoodaun, Lough and Roo West. The number of families collected using the box method appeared to level off after sampling of $33000 \mathrm{~cm}^{2}$ of bottom at both Lough Coy and Roo West, while the Caranavoodaun curve continued to rise. The number of families taken with the pond net continued to rise in a slow step-wise fashion as the area sampled increased.

The species accretion curves show more continuous and steeper increases for both methods and again illustrate the disparity in species richness between methods (Fig. 3). The box species accretion curves continued to increase until the final sample in all three turloughs, indicating both methods failed to record the full species richness for the sites. This is to be expected as taxon accretion curves are unlikely to ever reach an asymptote (Mackey et al., 1984). After $29484 \mathrm{~cm}^{2}$ or eight samples, however, $89 \%$ of all species were recorded at both Caranavoodaun and Roo West and $94 \%$ at Lough Coy, using the box method.

NMS was used to ordinate samples using the proportional abundance of species. Before ordination, species occurring in $5 \%$ or less of sample units were removed and the data set was transformed using an arcsine square root transformation. The Sorensen distance measure was used on random starting configurations. Three dimensions captured most of the variance in macroinvertebrate communities, with axes one, two and three containing 41.3, 20.2 and $16.9 \%$, respectively, of the information (cumulative $=78.5 \%$ ). Higher dimensions improved the model very little. Axis one and two (cumulative $=61.5 \%$ ) are shown here 


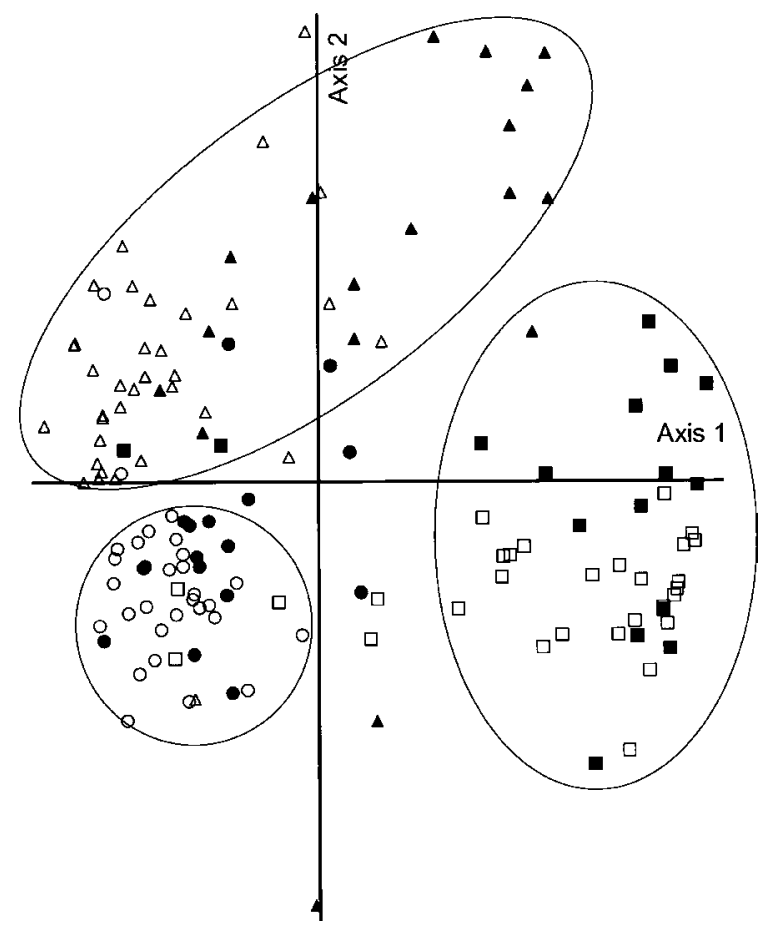

Figure 4. Nonmetric Multidimensional Scaling plot of samples using the proportional abundance of species. Circles represent Caranavoodaun; squares, Lough Coy and triangles, Roo West. Open symbols are pond net samples and closed symbols are box samples.

(Fig. 4). The final three-dimensional solution took 80 iterations, had a final stress of 17.54 and a final instability of 0.00042 . A Monte Carlo test performed with 20 randomized runs gave a probability of 0.048 that a similar final stress could have been obtained by chance. The plot shows a broad separation of the samples according to turlough. Samples from Lough Coy separated from those of Caranavoodaun and Roo West along axis one, while Caranavoodaun and Roo West samples were split along axis two. It is also evident that within the turlough clusters there is a separation of samples according to sampling method, particularly at Roo West.

\section{Discussion}

Biological monitoring of the invertebrate fauna of water bodies requires that samples be representative of the community present. In priority habitats, such as turloughs, which are often distinguished by rare species and assemblages, it is crucial to retrieve as close to the full species compliment as possible (Cao et al., 1998). Clearly, for the same investment of operator energy and time, the box method was far more successful than the pond net method in sampling the macroinvertebrate species richness of turloughs. Other quantitative devices have been described as less successful than pond nets in recording taxonomic richness (Macan, 1977; Mackey et al., 1984; Humphries et al., 1998). Hilsenhoff (1969) found, however, that his quantitative artificial substrate sampler collected more lotic taxa than a pond net.

Although the overall species richness was considerably greater using the box at all three turloughs, there was no clear difference in the effectiveness of the methods at the $1000 \mathrm{~cm}^{2}$ level. Yet, the box method did prove to be significantly more effective than the pond net in sampling beetle diversity and density at the $1000 \mathrm{~cm}^{2}$ level, allowing vigorous investigation of the dense vegetation, into which beetles dive when disturbed.

At Lough Coy, the significantly greater catch of macroinvertebrates per $1000 \mathrm{~cm}^{2}$ taken with the pond net can be explained by the dominance of corixids in those samples. Humphries et al. (1998) also found Hemiptera dominated pond net, sweep samples from lowland rivers. The abundance of corixids in pond net samples, along with the fact that Dytiscus spp. were captured at Caranavoodaun and Lough Coy using the pond net, but not with the box, suggests that the box method underestimated and may be inappropriate for sampling larger and faster swimming invertebrates.

Although neither method recorded all families/ species, each pond net taxon accretion curve appeared to approach an asymptote. This suggests the maximum potential of the method was being reached and that pond nets are not capable of capturing some of the more elusive turlough species, including those firmly anchored in the substrata. While further box sampling may have increased the diversity recorded, it would have been prohibitively time consuming.

The differences between methods were not sufficiently large to misclassify many samples using NMS. Both methods were successful in separating the turloughs, indicating each is sufficient to identify broad patterns among sites. That pond net 
samples were more tightly clustered and more clearly separated than box samples, reflects the greater specificity of box samples, demonstrated by the high overall diversity, but low diversity per $1000 \mathrm{~cm}^{2}$. Box samples appeared to portray more accurately the natural aggregation of species.

It may be possible to use a combination of data gathered by both methods to segregate turloughs using NMS. The separation of samples according to sampling method indicates the methods are not directly comparable, however, and a combination of the methods could not be used to examine within-turlough patterns.

The high final stress value for the NMS probably reflects the large number of sampling units involved. While this reduces the robustness of the plot, it is possible to make a general interpretation. Separation of turloughs along axis one appeared to be determined by water permanence, the scarce summer water at Caranavoodaun and Roo West contrasting with the small permanent lake at Lough Coy. Differences between Caranavoodaun and Roo West identified along axis two, may reflect higher productivity and greater microhabitat diversity at Caranavoodaun.

\section{Conclusions}

Sampling with the box was more efficient and accurate than with the pond net. Pond netting, however, was protracted by the need to bottle sweeps individually and pooling sweeps to form a single sample per turlough would increase its efficiency. Despite this, an increase in the number of sweeps would be unlikely to reveal the full diversity of macroinvertebrates in a turlough. The box method was more thorough, if slightly more timeconsuming overall.

Part of the success of the box method was owing to its ability to capture organisms hidden in the more structurally complex parts of the substrata, such as amongst mosses or stones. By contrast the pond net sampled the water column more efficiently. The box method detected species aggregations and was suitable for investigating invertebrate microhabitats. Unlike the pond net, the box method was highly quantitative, enabling an expression of numbers per area of bottom or volume of water, and provided more reliable sampling. To test its objectivity, however, the box method should be tested for inter-operator differences. Pond nets have demonstrated significant inter-operator differences when used in streams (Furse et al., 1981; Mackey et al., 1984).

Turloughs are unique and require a sampling strategy that reflects their high biodiversity importance. Sampling is complicated by the availability of water, which can vary among years and even among turloughs, and the variability of the substrata, which comprises semi-aquatic vegetation communities and physical structures such as limestone pavement and stone walls. The timing and frequency of turlough sampling needs consideration and testing. As a rule of thumb, we recommend turloughs are sampled a minimum of twice per year, once before the water recedes in spring/summer and once following 3 or 4 weeks flooding in autumn.

Adequate sampling of a turlough, particularly by those who lack experience of these systems, should incorporate both box and pond net methods. Based on our species accretion curves, we suggest ten box samples (or $36860 \mathrm{~cm}^{2}$ ) be taken per turlough and supplemented by a small number of sweeps with the pond net. This should maximise the quality of the data, while minimising the time and effort expended. The box samples should be taken from the variety of microhabitats present, preferably using stratified random sampling. Such a standardised sampling regime, although requiring further statistical validation, would be particularly appropriate to monitoring the persistence of the rare, relict and threatened turlough species.

The box sampling method could be applied to other freshwater habitats. Turloughs are recognised for the scarcity of their aquatic invertebrate populations (Reynolds, 1996, 2000), so the success of the box method could be expected to improve when applied to permanent, lentic littoral zones. The box is suitable for use in all shallow, lentic and lotic waters, from macrophyte beds to fine and coarse substrata, although modifications of the frame may be required to seal the bottom in cobbles and larger particle sizes (James \& Nicho1ls, 1961). While many quantitative aquatic samplers are large and/or heavy, our small frame was light and was not an encumbrance to the operator. 


\section{Acknowledgements}

The work was funded by the Higher Education Authority of Ireland. We also wish to thank Justin O'Connell and Maurice Martyn for their technical support in the field and laboratory. The authors are indebted to Prof. Garth Foster for confirmation of a number of beetle specimens.

\section{References}

Ali, T. H., J. M. C. Holmes \& J. N. R. Grainger, 1987. Diaptomus cyaneus Gurney, a freshwater copepod new to Britain and Ireland. Irish Naturalists' Journal 22: 240-241.

Bates, M., 1941. Field studies of the anopheline mosquitoes of Albania. Proceedings of the Entomological Society of Washington 43: 39-58.

Bilton, D. T., 1988. A survey of aquatic Coleoptera in central Ireland and the Burren. Bulletin of the Irish Biogeographical Society 11: 77-94.

Bilton, D. T. \& D. A. Lott, 1991. Further records of aquatic Coleoptera from Ireland. Irish Naturalists' Journal 23: 389397.

Bradish, S., Á. O Connor \& T. Reed, 2002. New records of the water beetles Berosus signaticollis (Charpentier) and Graptodytes bilineatus (Sturm) in turloughs. Irish Naturalists' Journal 27: 83-84.

Cao, Y., D. D. Williams \& N. E. Williams, 1998. How important are rare species in aquatic community ecology and bioassessment? Limnology and Oceanography 43: 1403-1409.

Cheal, F., J. A. Davis, J. E. Growns, J. S. Bradley \& F. H. Whittles, 1992. The influence of sampling method on the classification of wetland macroinvertebrate communities. Hydrobiologia 257: 47-55.

Cox, R., J. F. Wright, M. T. Furse \& D. Moss, 1995. RIVPACS III (River InVertebrate Prediction and Classification System) User Manual. Report to the National Rivers Authority.

Coxon, C., 1987a. The spatial distribution of turloughs. Irish Geography 20: 11-23.

Coxon, C., 1987b. An analysis of the characteristics of turloughs using multivariate statistical techniques. Irish Geography 20: 24-42.

Coxon, C., 1994. Carbonate Deposition in Turloughs (Seasonal Lakes) on the Western Limestone Lowlands of Ireland. I: Present day processes. Irish Geography 27: 14-27.

Croset, H., B. Papierot, J. A. Rioux, A. Gabinaud, J. Cousserans \& D. Arnaud, 1976. Absolute estimates of larval populations of culicid mosquitoes: comparison of 'capturerecapture', 'removal' and 'dipping' methods. Ecological Entomology 1: 251-256.

Crossman, J. S. \& J. Cairns Jr., 1974. A comparative study between two different artificial substrate samplers and regular sampling techniques. Hydrobiologia 44: 517-522.

Cummins, K. W., 1962. An evaluation of some techniques for the collection and analysis of benthic samples with special emphasis on lotic waters. The American Midland Naturalist 67: 477-504.

de Eyto, E., 1999. The ecology of the family Chydoridae (Branchiopoda, Anomopoda) and its application to lake monitoring. Unpublished PhD Thesis, University of Dublin, Trinity College, Dublin.

Duigan, C., 1988. The Cladocera (Crustacea) of Lough Ree and neighbouring waterbodies in Ireland. Bulletin of the Irish Biogeographical Society 11: 100-113.

Duigan, C. A. \& D. G. Frey, 1987a. Eurycercus glacialis, a chydorid cladoceran new to Ireland. Irish Naturalists' Journal 22: 180-183.

Duigan, C. A. \& D. G. Frey, 1987b. Eurycercus glacialis in Ireland (Cladocera, Chydoridae). Internationale Revue der Gesampten Hydrobiologie 72: 235-249.

Elliott, J. M. \& P. A. Tullet, 1978. A bibliography of samplers for benthic invertebrates. Freshwater Biological Association, Scientific Publication No. 4, Ambleside.

Elliott, J. M. \& K. H. Mann, 1979. A key to the British freshwater leeches. Freshwater Biological Association, Scientific Publication No. 40, Ambleside.

Elliott, J. M., U. H. Humpesch \& T. T. Macan, 1988. Larvae of the British Ephemeroptera. Freshwater Biological Association, Scientific Publication No. 49, Ambleside.

Fitter, R. \& R. Manuel, 1994. Lakes, rivers, streams \& ponds of Britain and north-west Europe. Collins Photo Guide, Harper Collins, Hong Kong.

Flanagan, P. J. \& P. F. Toner, 1972. The National Survey of Irish Rivers. A Report on Water Quality. An Foras Forbartha, WR/R1, Dublin.

Foster, G. N., B. H. Nelson, D. T. Bilton, D. A. Lott, R. Merrit, R. S. Weyl \& M. D. Eyre, 1992. A classification and evaluation of Irish water beetle assemblages. Aquatic Conservation: Marine and Freshwater Ecosystems 2: 185-208.

Friday, L. E., 1988. A key to the adults of British water beetles. Field Studies Council Publication 189.

Furse, M. T., J. F. Wright, P. D. Armitage \& D. Moss, 1981. An appraisal of pond-net samples for biological monitoring of lotic macro-invertebrates. Water Research 15: 679-689.

Gledhill, T., D. W. Sutcliffe \& W. D. Willaims, 1993. British Freshwater Crustacea Malacostraca: a key with ecological notes. Freshwater Biological Association, Scientific Publication No. 52, Ambleside.

Good, J. A. \& F. T. Butler, 2001. Turlough pastures as a habitat for Staphylinidae and Carabidae (Coleoptera) in south-east Galway and north Clare, Ireland. Bulletin of the Irish Biogeographical Society 25: 74-94.

Goodwillie, R., S. Heery \& S. Keane, 1997. Wetland vegetation in the Gort lowlands. In Jennings, O'Donovan \& Partners (eds), An Investigation of the Flooding Problems in the Gort-Ardrahan Area of South Galway, Ecology Baseline Study. OPW, Dublku 1-131.

Goodwin, M. H. Jr. \& D. E. Eyles, 1942. Measurements of larval populations of Anopheles quadrimaculatus, Say. Ecology 23: 376 .

Grainger, J. N. R. \& J. M. C. Holmes, 1989. Further records of Diaptomus cyaneus Gurney, (Crustacea: Copepoda) from temporary waterbodies in Ireland. Irish Naturalists' Journal 23: $160-161$ 
Hilsenhoff, W. L., 1969. An artificial substrate device for sampling benthic stream invertebrates. Limnology \& Oceanography 14: 465-471.

Humphries, P., J. E. Growns, L. G. Serafini, J. H. Hawking, A. J. Chick \& P. S. Lake, 1998. Macroinvertebrate sampling methods for lowland Australian rivers. Hydrobiologia 364: 209-218

I.S.O., 1985. Methods of biological sampling - Guidance on hand-net sampling of aquatic benthic macro-invertebrates. International Standard 7828, International Organisation for Standardization, Geneva.

James, H. G. \& C. F. Nicholls, 1961. A sampling cage for aquatic insects. The Canadian Entomologist 939: 1053-1055.

Lott, D. A. \& D. T. Bilton, 1991. Records of Coleoptera from Irish wetland sites in 1989. Bulletin of the Irish Biogeographical Society 14: 60-72.

Macan, T. T., 1958. Methods for sampling the bottom fauna in stony streams. Mitteilungen der Internationalen Vereiningung für Theoretische und Angewandte Limnologie 8: $1-21$.

Macan, T. T., 1977. The fauna in the vegetation of a moorland fishpond as revealed by different methods of collecting. Hydrobiologia 55: 3-15.

Macan, T. T. \& R. D. Cooper, 1977. A key to the British freshand brackish- water gastropods. Freshwater Biological Association, Scientific Publication No. 13, Ambleside.

Mackey, A. P., D. A. Cooling \& A. D. Berrie, 1984. An evaluation of sampling strategies for qualitative surveys of macro-invertebrates in rivers, using pond nets. Journal of Applied Ecology 21: 515-534.

MacGowran, B., 1979. Rorippa islandica (Oeder ex Murray) Borbas in turloughs of south east Galway (H 15). Irish Naturalists' Journal 19: 326-327.

Maitland, P. S., 1969. A simple corer for sampling sand and finer sediments in shallow water. Limnology and Oceanography: 151-156.

Marchant, R., A. Hirst, R. Norris, R. Butcher, L. Metzeling \& D. Tiller, 1997. Classification and prediction of macroinvertebrate assemblages from running waters in Victoria, Australia. Journal of the North American Benthological Society 16: 664-681.

Metzeling, L. \& J. Miller, 2001. Evaluations of the sample size used for the rapid bioassessment of rivers using macroinvertebrates. Hydrobiologia 444: 159-170.

Muzaffar, S. B. \& M. H. Colbo, 2002. The effects of sampling technique on the ecological characterization of shallow benthic macroinvertebrate communities in two Newfoundland ponds. Hydrobiologia 477: 31-39.

Ní Bhríaín, B., M. Sheehy Skeffington \& M. Gormally, 2002. Conservation implications of land use practices on the plant and carabid communities of two turloughs in Co. Galway, Ireland. Biological Conservation 105: 81-92.

O’Connell, M., J. B. Ryan \& B. A. MacGowran, 1984. Wetland communities in Ireland: a phytosociological review, In Moore, P. D. (ed.), European Mires. Academic Press, London: 303-364.

O Connor, Á., 2000. The development of aquatic macroinvertebrate communities in two artificial wetlands on Irish cutaway bog, with particular reference to Corixidae (Hemiptera
Heteroptera). Unpublished PhD Thesis, University of Dublin, Trinity College, Dublin.

Owen, J. A., 1997. Beetles (Coleoptera) recorded from variousjrish sites in 1993, 1994 and 1996. Bulletin of the Irish Biogeographical Society 20: 136-154.

Praeger, R. L., 1932. The flora of the turloughs: a preliminary note. Proceedings of the Royal Irish Academy, Section B XLI: $32-45$.

Reynolds, J. D., 1982. Ecology of turloughs (Vanishing Lakes) in the Burren, Western Ireland. Transactions 14th International Congress of Game Biologists 14: 183-188.

Reynolds, J. D., 1985. Cladocera from Burren turloughs at Mullagh More, Co. Clare. Bulletin of the Irish Biogeographical Society 9: 51-54.

Reynolds, J. D., 1996. Turloughs, their significance and possibilities for conservation. In Reynolds, J. D. (ed.), The Conservation of Aquatic Systems. Royal Irish Academy, Dublin: 38-46.

Reynolds, J. D., 2000. Invertebrate communities of turloughs (temporary lakes) in south-east Galway, Ireland. Verhandlungen Internationale Vereinigung für Thoretische und und Angewandte Limnologie 27: 1679-1684.

Reynolds, J. D., C. Duignan, F. Marnell \& Á. O Connor, 1998. Extreme and ephemeral water bodies in Ireland. In Giller, P. S. (ed), Studies in Irish Limnology. Marine Institute, Dublin: 67-99.

Reynolds, J. D. \& F. Marnell, 1999. New records of Eurycercus glacialis (Cladocera: Chydoridae) in turloughs in south-east Galway. Irish Naturalists' Journal 26: 177-180.

Ryder, C., R. J. Me Donnell, M. J. Gormally \& L. Knutson, 2003. Colobaea distincta (Meigen): a sciomyzid (Diptera) new to Ireland with a key to the Irish species of the genus. Irish Naturalists' Journal 27: 184-186.

Ryder, C., J. Moran, R. J. Mc Donnell \& M. J. Gormally, in press. Nature conservation implications of grazing practices on the plant and dipteran communities of a turlough in Co. Mayo, Ireland. Biodiversity and Conservation.

SAC, 1978. Methods for biological sampling - Hand-net sampling of aquatic benthic macroinvertebrates. Methods for the Examination of Waters and Associated Materials, Standing Committee of Analysts, HMSO, London.

Savage, A. A., 1989. Adults of the British aquatic Hemiptera Heteroptera: a key with ecological notes. Freshwater Biological Association, Scientific Publication No. 50, Ambleside.

Turak, E. \& N. Waddell, 2002. Australia-Wide Assessment of River Health: New South Wales AusRivAs Sampling and Processing Manual. Monitoring River Health Initiative Technical Report no. 13, Commonwealth of Australia and NSW Environmental Protection Authority, Canberra and Sydney.

Wallace, I. D., B. Wallace \& G. N. Philipson, 1990. A key to the case-bearing caddis larvae of Britain and Ireland. Freshwater Biological Association, Scientific Publication No. 51, Ambleside.

Wright, J. F., D. Moss, P. D. Armitage \& M. T. Furse, 1984. A preliminary classifications of running-water sites in Great Britain based on macro-invertebrate species and the prediction of community type using environmental data. Freshwater Biology 14: 221-256. 